\title{
DOSSIER
}

\section{Over kennislacunes en lokale mogelijkheden}

\author{
Albert-Jan Kruiter \& Sarah L. de Lange*
}

\section{Onder redactie van Albert-Jan Kruiter \& Sarah L. de Lange}

2014 wordt een tumultueus jaar. Niet alleen moeten alle 403 gemeenten hun organisaties klaarstomen voor de 'drie decentralisaties', op 19 maart vinden tevens de gemeenteraadsverkiezingen plaats. Met andere woorden, in het laatste jaar voordat het Rijk 16 miljard euro naar de gemeenten overhevelt en de gemeenten verantwoordelijk worden voor de jeugdzorg, de begeleiding van de Algemene Wet Bijzondere Ziektekosten (AWBZ) en de Participatiewet (waaronder regelingen als de Wet arbeidsongeschiktheidsvoorziening jonggehandicapten (Wajong) gaan vallen), kiezen de inwoners van die gemeenten nieuwe vertegenwoordigers. Vanuit dit perspectief zijn het belangrijke verkiezingen, immers, het zijn de gemeenteraden die in veel gevallen de verordeningen en plannen die ten grondslag liggen aan de gedecentraliseerde taken moeten opstellen en goedkeuren. Dat is geen geringe opgave voor de gemeenteraadsleden die binnenkort gekozen worden, niet in de laatste plaats omdat de contouren van het decentralisatieproject (nog) vaag zijn.

Ten minste zes kwesties lijken nog opgehelderd te moeten worden. Ten eerste is nog steeds niet bekend welke taken precies op het conto van de gemeenten komen. Daarnaast schuift het Rijk met taken die reeds aan de gemeenten zijn toegezegd. Persoonlijke verzorging zou bijvoorbeeld eerst door gemeenten worden uitgevoerd, maar werd uiteindelijk toch aan de verzekeraars gegund. Ten tweede bestaat er geen onomstreden methode waarop gemeenten maatwerk kunnen leveren. En juist maatwerk zou zorg-, hulp- en dienstverlening op lokaal niveau zowel beter als goedkoper kunnen maken. Althans, zo luidt de gangbare hypothese van het Rijk. Ten derde zijn nog lang niet alle data, informatie en kennis beschikbaar op basis waarvan gemeenten beleid kunnen voeren. Ten vierde is nog niet duidelijk of het nu de bedoeling is dat gemeenten de decentralisaties verschillend aanpakken, of dat er enige mate van standaardisatie ontstaat. Bovendien kan die standaardisatie weer op verschillende manieren tot stand komen. Ten vijfde zou er met de decentralisaties in potentie ruimte voor gemeenten moeten ontstaan om de verzorgingsstaat van de toekomst lokaal vorm te geven. Maar waar die ruimte precies zit - in de financiën, de regelgeving of de institutionele samenwerking -, is nog niet duidelijk. Tot slot is het de vraag hoe gemeenteraden met de decentralisaties omgaan. Krijgen ze genoeg te zeggen (of gaan gemeenten vooral op regionaal niveau samenwerken?) en zijn nieuwe raadsleden op tijd klaar

* $\quad$ Albert-Jan Kruiter is redactielid van Beleid en Maatschappij. Sarah L. de Lange is redactielid van Beleid en Maatschappij. 
voor de decentralisaties? Kortom: het wordt een tumultueus jaar. Voor inwoners, voor lokale en nationale politici, voor Haagse en gemeentelijke beleidsmakers, voor uitvoerders en ja, ook voor wetenschappers.

Om die reden leek het de redactie van B en $\mathrm{M}$ opportuun om een aanzet te geven tot kennisvorming. Immers, als het rondom de decentralisaties ergens aan ontbreekt is het een gedegen body of knowledge. Om die reden hebben we een aantal experts gevraagd hun licht te laten schijnen over de uitdagingen die de decentralisaties bieden. Zo gaat Roel in 't Veld (Tilburg Sustainabillity Centre) in op de vraag of er een wetenschappelijke decentralisatietheorie bestaat en hoe decentralisaties in empirische zin uitpakken. In 1979 constateerde hij reeds dat het ontbrak aan een decentralisatietheorie. Maar is dat vandaag de dag nog steeds zo? Martijn van der Steen en Mark van Twist (Nederlandse School voor Openbaar Bestuur) gaan in op de organisationele kant van de decentralisaties: welke strategieën kunnen gemeenten hanteren? Volgens de auteurs vergezellen structurele onzekerheid en complexiteit de decentralisaties. Gemeenten kunnen enerzijds die complexiteit proberen te beheersen en anderzijds zich proberen wendbaar op te stellen. Gemeenten kunnen, kortom, weerbaar of wendbaar zijn. De auteurs bespreken beide opties. Duco Bannink, Hans Bosselaar, Judith van der Veer en Willem Trommel (onderzoeksgroep Local Welfare van de Vrije Universiteit Amsterdam) kijken terug en vergelijken de manier waarop de Wet maatschappelijke ondersteuning en de Wet Werk en bijstand gedecentraliseerd zijn. Wat kunnen we van deze eerdere decentralisatieoperaties leren? Ze constateren dat decentralisatie van beleid niet altijd integratie van beleid betekent. Dat veroorzaakt inhoudelijke en financiële risico's voor gemeenten. Vervolgens gaan Nico de Boer en Jos van der Lans (zelfstandig onderzoekers en auteurs van het boek DEcentraal) in op de vraag waar de kansen voor de lokale politiek liggen. Bieden de decentralisaties ook mogelijkheden om de lokale democratie te revitaliseren? Dat is zeker het geval. Mits raadsleden niet zozeer het gemeentebestuur als object van aandacht kiezen, maar de raadzaal weer zien als een plek waar het lokale algemene belang wordt geformuleerd. En als ze die raadzaal weer opzetten voor gesprekken met burgers en initiatiefnemers van burgerinitiatieven. In principe versterken de decentralisaties de lokale politiek, Aldus De Boer en Van der Lans. Tot slot plaatst Klaartje Peters (bijzonder hoogleraar lokaal en regionaal bestuur aan de Universiteit Maastricht) de Nederlandse decentralisaties in een internationaal perspectief. Door de zorgaanbieders, de transitiebureaus, de ministeries en de gemeentehuizen is de afgelopen jaren veel verwezen naar de Deense casus. Volgens sommigen het voorland van succesvolle decentralisaties, voor anderen juist een voorbeeld van hoe het niet moet. Peters bespreekt de casus Denemarken en beschrijft wat we van zowel de opzet als de uitvoering van de Deense hervormingen kunnen leren. Hierbij springen onder meer het feit dat decentralisatie vaak gepaard gaat met financiële centralisatie, het risico op ongelijkheid tussen gemeenten (in het beroep dat op zorgvoorzieningen wordt gedaan en in het niveau van de uitgaven), en de moeilijkheden die kleine gemeenten ondervinden om zorg aan bijzondere doelgroepen te leveren, in het oog. Daarnaast moet worden geconcludeerd dat op basis van de decentralisaties in Denemarken geen hel- 
dere lessen over eventueel winst of verlies van bestuurlijke efficiency en versterking of verzwakking van de lokale democratie getrokken kunnen worden.

We bieden met dit dossier dus vijf verschillende perspectieven op de decentralisaties: een wetenschappelijk-theoretisch perspectief (In 't Veld), een organisationeel perspectief (Van der Steen en Van Twist), een juridisch en uitvoerend perspectief (Bannink, Bosselaar, Van der Veer en Trommel), een democratisch politiek perspectief (de Boer en Van der Lans) en een internationaal vergelijkend perspectief (Peters). Daarmee pretenderen we niet een compleet dossier te genereren. Wel doen we een aanzet om te komen tot een body of knowledge. Want zonder kennis zal decentralisatiebeleid grossieren in onverwachte en ongewenste effecten. En hoewel die effecten nooit te voorkomen zijn, ontslaat dat ons niet van de verplichting om er zo goed mogelijk op te anticiperen. 